\title{
Sistem Informasi Layanan Online Menggunakan Enkripsi MD5 Untuk Pelayanan Warga Berbasis Web
}

\author{
Yohanes Murfi ${ }^{1}$, Sugiyatno ${ }^{1, *}$, Mugiarso ${ }^{1}$ \\ * Korespondensi: e-mail: sugiyatno@dsn.ubharajaya.ac.id
}

\begin{abstract}
1 Program Studi Teknik Informastika Fakultas Teknik, Universitas Bhayangkara Jakarta Raya; Jl. Raya Perjuangan, Marga Mulya, Bekasi Utara, Jawa Barat 17121. Telp: 02188955882, 889955883, e-mail: yohanesmurfi@gmail.com, sugiyatno@dsn.ubharajaya.ac.id mugiarso@dsn.ubharajaya.ac.id

Submitted: 11 Maret 2020

Revised: 1 April 2020

Accepted: 22 April 2020

Published: 20 Mei 2020
\end{abstract}

\section{Abstract}

Online Service Information System Uses MD5 Encryption for Web-Based Citizens' Services for residents of the purple cottage in Central Kaliai, North Bekasi. From the research found the findings in the cover letter service. The application uses the codeigniter framework template, and uses the MYSQL database, PHP Myadmin. this study uses the waterfall method. The results of this study improve efficiency in terms of community service, especially for submission services.

Keywords: Service Information System, PHP, Database, MySQL

\section{Abstrak}

Sistem Informasi Layanan Online Menggunakan Enkripsi MD5 untuk Layanan Warga Berbasis Web untuk warga pondok ungu di Kaliai Tengah, Bekasi Utara. Dari penelitian ditemukan temuan dalam layanan surat pengantar. Aplikasi ini menggunakan templat kerangka codeigniter, dan menggunakan database MYSQL, PHP Myadmin. penelitian ini menggunakan metode waterfall. Hasil penelitian ini meningkatkan efisiensi dalam hal layanan masyarakat, terutama untuk layanan pengiriman.

Kata Kunci: Service Information System, PHP, Database, MySQL

\section{Pendahuluan}

Rukun Warga atau disingkat RW adalah sebuah lembaga kemasyarakatan yang dibentuk melalui musyawarah pengurus RT di wilayah kerjanya dalam rangka pelayanan pemerintah dan masyarakat yang diakui dan dibina oleh Pemerintah Daerah yang ditetapkan oleh Lurah. Sedangkan Rukun Tetangga atau RT adalah lembaga yang dibentuk melalui musyawarah masyarakat setempat dalam rangka pelayanan pemerintahan dan kemasyarakatan yang ditetapkan oleh Pemerintah Desa atau Lurah.

Pada saat ini di RW011 kendala yang dihadapi saat warga mempunyai keperluan untuk pengajuan permohonan surat pengantar atau surat keterangan yang dikeluarkan dari RT maupun RW terkendala karena tidak setiap saat ketua

RW maupun RT berada di tempat dikarenakan harus bekerja dan mempunyai kesibukan lainnya. Sehingga proses pengajuan permohonan surat tersebut harus di tunda sampai warga bertemu dengan ketua RW atau RT. Permasalahan lain yang ada pada rukun tetangga di wilayah ini adalah kegiatan pengolahan dalam surat menyurat dan pendataan penduduk masih di lakukan secara manual, sehingga data yang sudah lama mudah rusak sehingga tidak tersusun dengan rapi dan teratur. Hal ini menyebabkan sulitnya melakukan evaluasi kegiatan yang ada di Rukun Tetangga, 
demikian juga lambatnya proses pelaporan kegiatan yang dilakukan di Rukun Tetangga di wilayah tersebut. Serta kendala yang dialami oleh RT/RW dalam menjalankan tugasnya adalah sistem informasi yang tidak efektif dan efisien, sehingga menyulitkan dan memperlambat dalam proses pelaporan dan perarsipan data kependudukan.

Berdasarkan dari permasalahan tersebut, maka ada beberapa solusi yang ditawarkan diantaranya masalah yang lebih spesifik agar pemberian pelayanan dan pemberian informasi yang akan didapat oleh warga masyarakat dapat dimanfaatkan secara maksimal. Maka perlu dibangun sebuah sistem layanan online warga untuk RT/RW 03/011 Pondok Ungu Permai, Kelurahan Kaliabang Tengan Kecamatan Bekasi Utara, Kota Bekasi. Antara lain Surat Pengantar RT untuk Membuat KTP , Surat Pengantar RT Untuk Pembuatan SKCK , Surat Pengantar RT Untuk Pembuatan Kartu Keluarga (KK) , Surat Pengantar RT untuk Nikah, Surat Pengantar RT Untuk SKU (Surat Keterangan Usaha), Surat Pengantar RT Untuk SKTM (Surat Keterangan Tidak Mampu), Surat Pengantar RT Untuk Pindah Alamat, Surat Pengantar RT Untuk Ahli Waris, Surat Pengantar RT Belum Memiliki Rumah , Surat Pengantar RT Untuk Cerai, Surat Pengantar RT Untuk Domisili , Surat Pengantar RT Terbaru (Format Surat), Surat Pengantar RT Untuk Akte Kelahiran , Surat Pengantar RT Untuk Keterangan Miskin, Surat Pengantar RT Untuk ljin Usaha. Sistem layanan online warga ini diharapkan dapat membantu memudahkan Ketua RT/RW 03/011 dalam mempermudah dalam proses pembuatan surat pengantar yang berfungsi menggantikan pencatatan secara manual serta diharapkan dapat menggantikan efisensi kerja dan kecepatan dalam pengambilan keputusan dan dapat menjadi solusi dari masalah yang ada.

Pembatasan masalah pada penelitian ini yaitu: 1). Perancangan sistem informasi warga ditujukan ke pondok ungu permai RT 03 / RW 011, Sehingga semua informasi dapat tersalurkan dengan cepat dan mudah. 2). Sistem ini hanya dioperasikan oleh ketua RT 03 / RW 011 atau sekretaris RT 03 / RW 011, bendahara RT 03 / RW 011. 3)Sistem yang akan di buat adalah system informasi berbasis web, aplikasi pengembangan surat pengantar RT/RW online ini di buat dengan bahasa pemrograman PHP dan database MySQL. 4). Hanya membahas tentang pembuatan surat pengantar RT/RW secara online, Output yang di hasilkan berupa surat pengantar, seperti Surat Pengantar RT untuk Membuat KTP , Pembuatan SKCK, Pembuatan Kartu Keluarga (KK), Nikah , SKU (Surat Keterangan Usaha), SKTM (Surat Keterangan Tidak Mampu), Pindah Alamat, Ahli Waris, Belum Memiliki Rumah, Untuk Cerai, Untuk Domisili, Akte Kelahiran, Keterangan Miskin dan ljin Usaha.

\section{Metode Penelitian}

Metode Pengumpulan data dalam penelitian ini yang digunakan adalah: 1). Metode Observasi, Pada metode ini yaitu melakukan penelitian dan pengamatan secara langsung mengenai kegiatan dan keadaan lingkungan RW, khususnya pada sistem kerja RW dan Sekretaris. 2). Metode Wawancara, Pada metode ini langsung mewawancarai Ketua RW, Sekretaris , penjaga RW 011 dan masyarakat setempat di pondok ungu permai blok G7 no15 RT 03 / RW 011. 3). Studi Pustaka, Salah satu metode pengumpulan data yang sangat membantu dalam menyelesaikan penelitian ini adalah 
studi pustaka. Pengumpulan data dengan melalui studi pustaka adalah dengan cara memanfaatkan sumber bacaan yang ada hubungan dengan obyek untuk memperoleh kesimpulan para ahli dengan menempatkan kesimpulan tersebut.

Metode Pengembangan Software dalam perancangan software Sistem Informasi Layanan Online Berbasis Web Untuk Pelayanan Warga, menggunakan metode Waterfall yang terdiri dari: Pertama, Communication (Project Initiation \& Requirements Gathering) Sebelum memulai pekerjaan yang bersifat teknis, sangat diperlukan adanya komunikasi dengan customer demi memahami dan mencapai tujuan yang ingin dicapai. Hasil dari komunikasi tersebut adalah inisialisasi proyek, seperti menganalisis permasalahan yang dihadapi dan mengumpulkan data-data yang diperlukan, serta membantu mendefinisikan fitur dan fungsi software. Pengumpulan data-data tambahan bisa juga diambi dari jurnal , artikel dan internet. Kedua, Planning (Estimating, Scheduling, Tracking) Tahap berikutnya adalah tahapan perencanaan yang menjelaskan tentang estimasi tugas-tugas teknis yang akan dilakukan, resiko-resiko yang dapat terjadi, sumber daya yang diperlukan dalam membuat sistem, produk kerja yang ingin dihasilkan, penjadwalan kerja yang akan dilaksanakan, dan tracking proses pengerjaan sistem. Ketiga, Modeling (Analysis \& Design) Tahapan ini adalah tahap perancangan dan permodelan arsitektur sistem yang berfokus pada perancangan struktur data, arsitektur software, tampilan interface, dan algoritma program. Tujuannya untuk lebih memahami gambaran besar dari apa yang akan dikerjakan. Keempat, Construction (Code \& Test) Tahapan Construction ini merupakan proses penerjemahan bentuk desain menjadi kode atau bentuk/bahasa yang dapat dibaca oleh mesin. Setelah pengkodean selesai, dilakukan pengujian terhadap sistem dan juga kode yang sudah dibuat. Tujuannya untuk menemukan kesalahan yang mungkin terjadi untuk nantinya diperbaiki. Kelima, Deployment (Delivery, Support, Feedback) Tahapan Deployment merupakan tahapan implementasi software ke customer, pemeliharaan software secara berkala, perbaikan software, evaluasi software, dan pengembangan software berdasarkan umpan balik yang diberikan agar sistem dapat tetap berjalan dan berkembang sesuai dengan fungsinya. (Pressman, 2015).

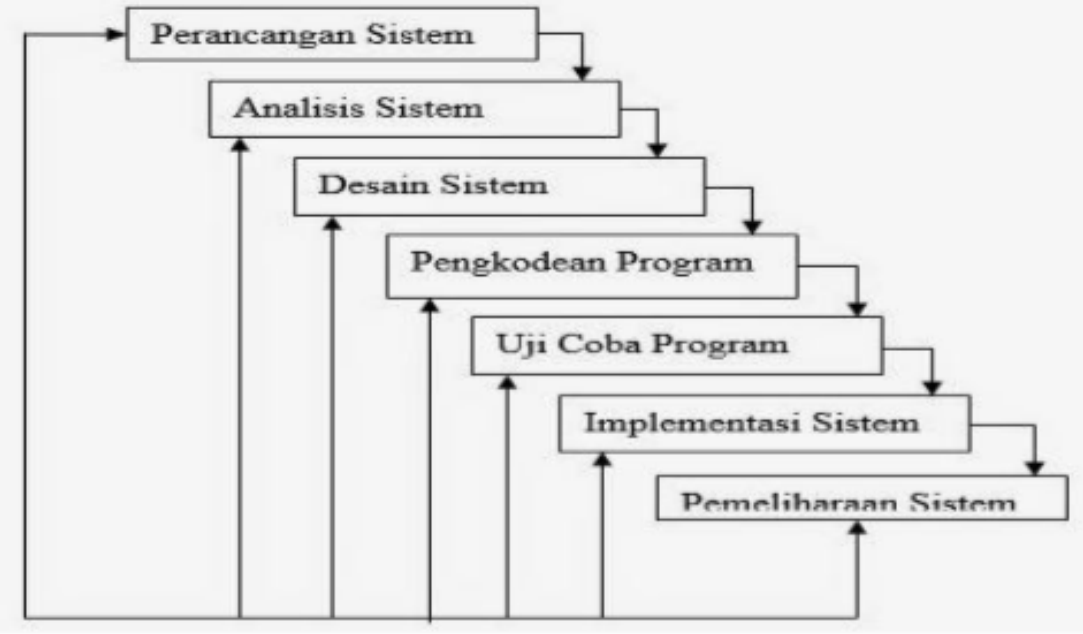

Sumber: (Pressman, 2015)

Gambar 1. Diagram alur penelitian. 
Pada Gambar 1 terlihat beberapa tahapan yaitu: 1. Requirement (analisis kebutuhan) Dalam tahap ini, analisis kebutuhan dilakukan dengan kegiatan observasi dan wawancara. Observasi dilakukan langsung ke warga RT dan RW terkait pelayanan kependudukan khususnya mengenai kegiatan permohonan surat warga mengenai kependudukan, sedangkan untuk wawancara dilakukan dengan melakukan wawancara terhadap pihak-pihak yang terlibat pelayanan kependudukan, tetapi pada penelitian ini hanya dilakukan wawancara terhadap aparat warga yang mengurusi masalah kependudukan seperti ketua RW dan sekertaris, Ketua RT dan sekertaris. Hal ini dikarenakan wawancara terhadap aparat warga yang mengurusi masalah kependudukan akan lebih efesien dan efektif. 2. Design System (desain sistem) Proses desain dilakukan dengan memperhatikan data yang telah terkumpul dari hasil observasi di lapangan yaitu yang berkaitan dengan kebutuhan sistem, alur metode yang digunakan dan pengguna sistem. Hal itu di lakukan supaya sistem yang dibuat sesuai dengan alur proses untuk di konsultasikan dan mendapatkan persetujuan oleh dosen pembimbing. 3. Coding \& Testing (penulisan sinkode program/ implementasi) Coding merupakan tahap implementasi dari desain. Desain yang telah dibuat kemudian diproses menjadi sebuah sistem dengan menggunakan coding. Proses coding dilakukan dengan menggunakan bahasa pemrograman PHP, My SQL dan XAMPP. Setelah pengkodean/ coding selesai dilakukan testing terhadap sistem yang telah dibuat untuk menemukan kesalahan-kesalahan terhadap sistem untuk diperbaiki. 4. Penerapan/ Pengujian Program (Integration \& Testing) Setelah dilakukan proses coding selanjutnya sistem diuji dengan pengujian blackbox testing. Blackbox testing merupakan salah satu metode pengujian perangkat lunak yang berfokus pada sisi fungsionalitas, khususnya pada input dan output aplikasi. Penerapan dari sistem dilakukan di rukun warga 011 blok g pondok ungu permai, Kecamatan bekasi utara, Kelurahan kaliabang tengah untuk memperoleh data validasi sistem, apakah sistem layak untuk diterapkan dilapangan. 5. Pemeliharaan (Operation \& Maintenance) Sistem yang telah dibuat dan disampaikan kepada pihak terkait dilapangan pasti mengalami perubahan karena sebuah kesalahan dan sistem masih asing di lapangan sehingga harus menyesuaikan diri.

Angket (Kuesioner) merupakan teknik pengumpulan data yang dilakukan dengan cara memberi seperangkat pertanyaan atau pernyataan tertulis kepada responden untuk dijawab (Sugiyono, 2011). Angket yang digunakan peneliti pada penelitian ini adalah angket untuk mengukur tingkat kelayakan suatu sistem yang akan dibuatkan.

Tabel 1. Kuesioner sebelum pembuatan sistem informasi pelayanan online warga.

\begin{tabular}{|c|c|c|c|}
\hline \multirow[t]{2}{*}{ No } & \multirow[t]{2}{*}{ Pertanyaan } & \multicolumn{2}{|c|}{ Jumlah Responden } \\
\hline & & $\mathrm{Ya}$ & Tidak \\
\hline 1. & $\begin{array}{l}\text { Menurut Bapak / Ibu, bagaimana permohonan permintan surat pengantar yang sedang berjalan di RW.011 } \\
\text { mudah/tidak mudah atau tidak? }\end{array}$ & 25 & 5 \\
\hline 2. & $\begin{array}{l}\text { Menurut bapak/ibu permohonan surat pengantar secara manual cukup efektif dijaman teknologi yang berkembang } \\
\text { saat ini iya/tidak? }\end{array}$ & 13 & 17 \\
\hline 3. & Apakah bapak/ibu setuju bila menerapkan sistem informasi layanan surat pengantar warga berbasis web iya/tidak ? & 22 & 8 \\
\hline 4. & $\begin{array}{l}\text { Apakah saat bapak/ibu melakukan permohonan surat pengantar dapat langsung bertemu dengan ketua rt/rw dengan } \\
\text { mudah? }\end{array}$ & 18 & 12 \\
\hline 5. & Kira-kira menurut bapak/ibu sistem informasi layanan surat pengantar dapat berjalan dengan baik ? & 23 & 7 \\
\hline 6. & Apakah bapa/ibu setuju apabila sistem informasi layanan online warga berbasis web di terapkan? & 27 & 3 \\
\hline & Total & 128 & 52 \\
\hline & Rata-rata & 21,3 & 8,7 \\
\hline
\end{tabular}

Sumber: Hasil Pengolahan Data (2019) 


\section{Hasil dan Pembahasan}

Perancangan Sistem Perancangan sistem ini bertujuan untuk membangun sistem informasi layanan online warga mengunakan $\mathrm{md} 5$ berbasis web guna meningkatkan pelayanan warga pada rukun warga dan rukun tetanga tersebut. Dalam perancangan sistem informasi layanan online warga mengunakan md5 berbasis web untuk peningkatan pelayanan warga pada RW.011/RT.03 Pondok ungu permai ini menggunakan metode Waterfall untuk pengembangan sistem tersebut. Pengembangan sistem menggunakan metode Waterfall ini dimaksud untuk memberikan gambaran secara rinci dengan menggunakan tahapan yang ada didalam metode Waterfall yaitu, analisa kebutuhan, desain sistem, penulisan sinkode program/ implementasi, Penerapan/ Pengujian Program, Pemeliharaan, security yang di pakai sebagai pengamanan sistem ini yaituh md5 Dan juga menggunakan UML (Unifield Modelling Language) sebagai penggambaran aktifitas-aktifitas proses yang ada pada perancangan sistem informasi layanan online warga mengunakan md5 berbasis web.

Use case Diagram Use case diagram dibawah menjelaskan kegiatan yang dilakukan RW, RT atau Warga terhadap sistem. Komponen use case diagram terdiri dari, aktor, use case, dan relation. Aktor adalah pemain, sedangkan use case adalah apa yang dimainkan atau dilakukan dengan relation sebagai penunjuknya.

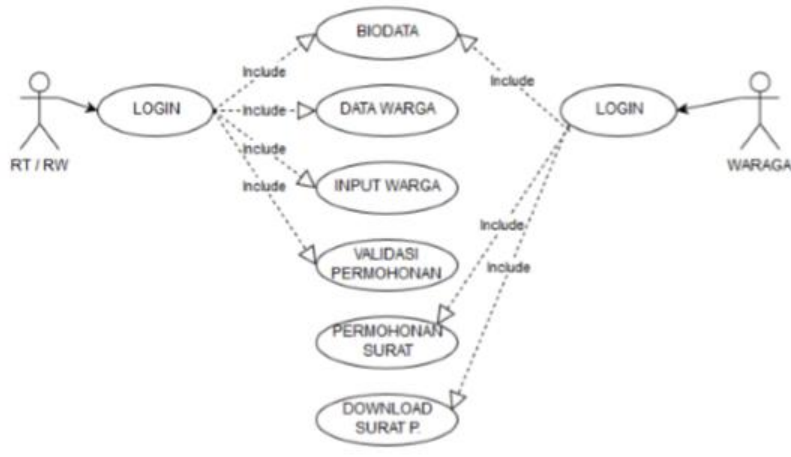

Sumber: Hasil Penelitian (2019)

Gambar 2. Use Case Diagram Sistem usulan

Use case diagram sistem yang akan dirancang ini menggambarkan tentang proses dan aktor yang berjalan di dalam sistem tersebut.

Activity Diagram Menggambarkan alur kerja atau kegiatan sebuah sistem atau proses bisnis atau menu yang ada didalam perangkat lunak. Yang diperhatikan disini adalah bahwa diagram aktivitas menggambarkan aktivitas sistem bukan apa yang dilakukan oleh aktor yang menjalankan aplikasi. Berikut ini adalah activity diagram login RW, RT, WARGA. menggambarkan aktivitasaktivitas yang terjadi dalam sistem informasi layanan online warga berbasis web: 


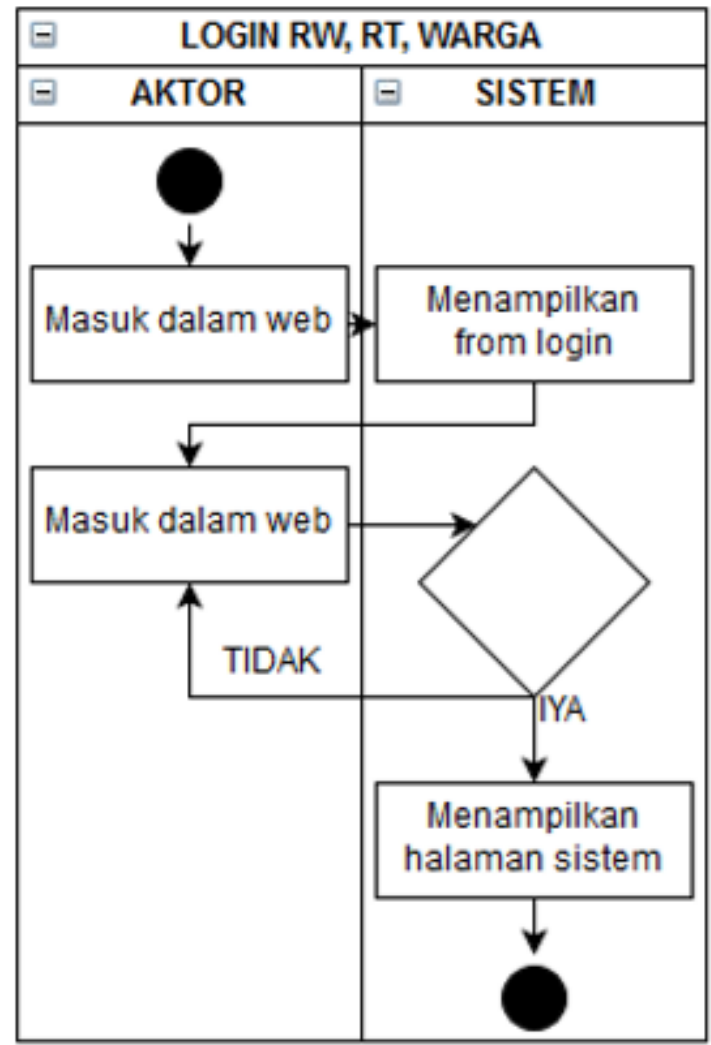

Sumber: Hasil Penelitian (2019)

Gambar 3. Activity diagram halaman login RW, RT, WARGA.

Sequence diagram menggambarkan kolaborasi dinamis antara sejumlah objek. Sequence menjelaskan interaksi antar objek yang disusun dalam suatu urutan waktu yaitu urutan kejadian yang dilakukan oleh seorang aktor dalam menjalankan sistem. Diagram ini menunjukkan bagaimana detail operasi yang dilakukan, pesan apa yang dikirim dan kapan terjadinya. Berikut adalah sequence diagram ketua RT validasi permohonan yang menjelaskan aliran pesan antar objek dalam aktivitas usecase dari rancangan aplikasi sistem yang diusulkan:

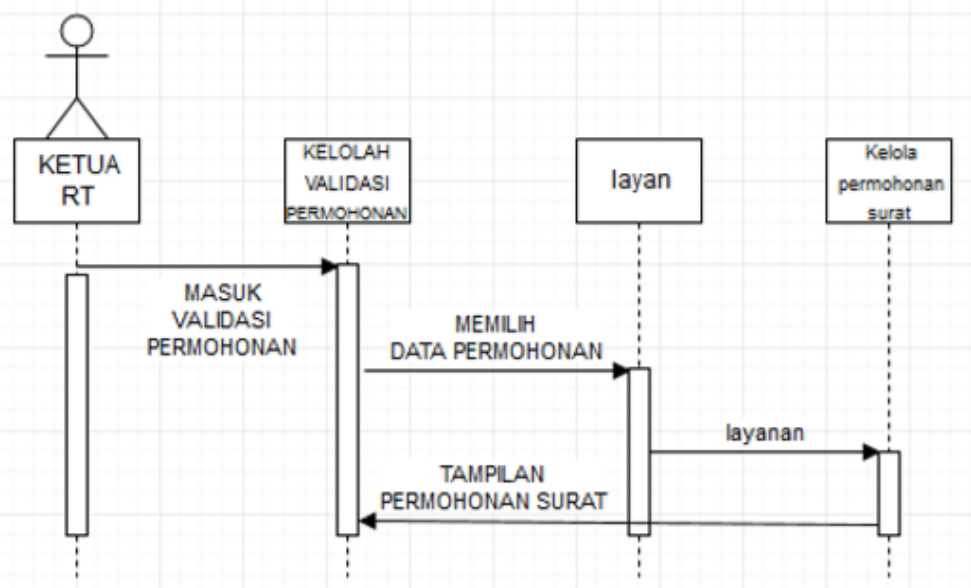

Sumber: Hasil Penelitian (2019)

Gambar 4. Sequence diagram ketua RT validasi permohonan. 
Class diagram menggambarkan hubungan antar table dan penjelasan detail tiap-tiap kelas didalam model desain dari sutu sistem, juga memperlihatkan aturan-aturan dan tanggung jawab entitas yang menentukan prilaku sistem.

Berikut adalah class diagram dari sistem informasi layanan online berbasis web:

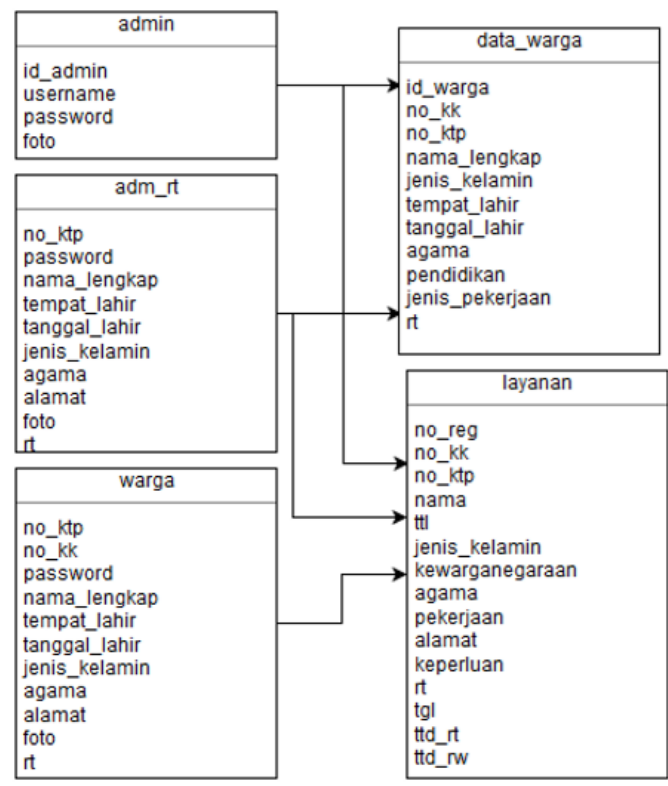

Sumber: Hasil Penelitian (2019)

Gambar 5. Class Diagram sistem informasi layanan online warga

Perancangan antarmuka sistem merupakan penggambaran untuk tampilan aplikasi yang akan dibuat. Perancangan antarmuka sistem ini masuk kedalam tahapan desain proses metode waterfall dimana pada perancangan antarmuka sistem ini menggambarkan proses apa saja yang ada pada aplikasi sistem informasi layanan online warga.

Desain Halaman Utama ini menggambarkan tampilan hallaman utama/dashboard setelah admin rw, ketua rt, warga berhasil login ke dalam aplikasi, berikut gambar dari desain interface halaman login:
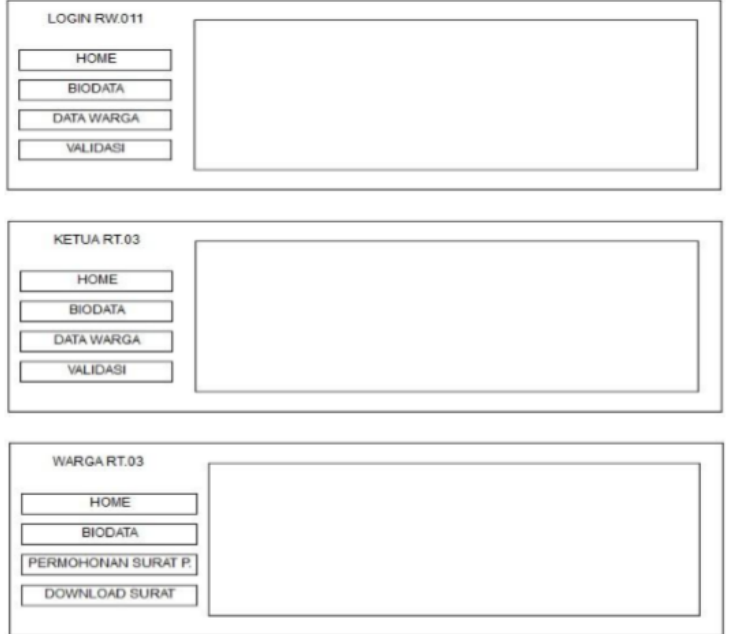

Sumber: Hasil Penelitian (2019)

Gambar 6. Desain Menu Home. 
Berikut ini merupakan rancangan tampilan antarmuka dari aplikasi yang telah dibuat yang terdiri dari halaman login admin.

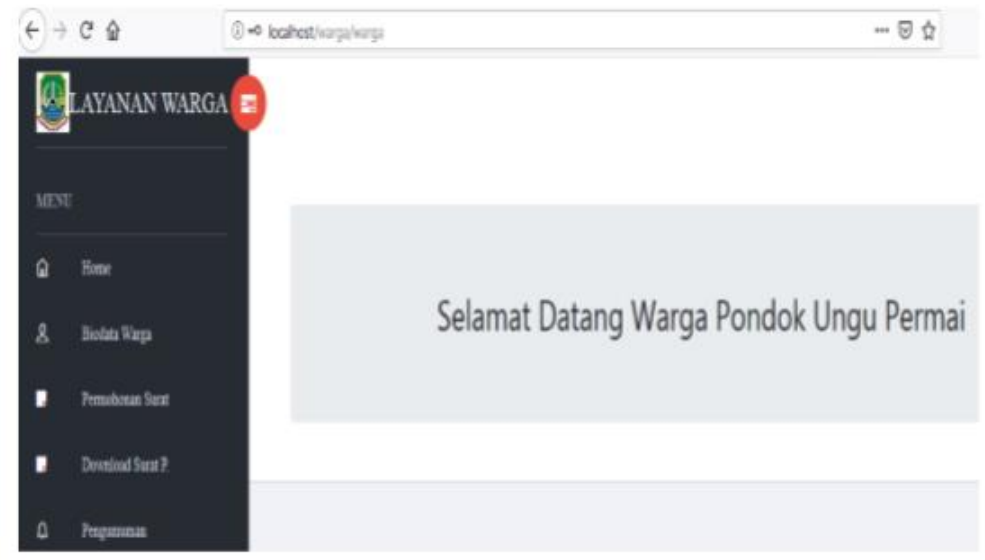

Sumber: Hasil Penelitian (2019)

\section{Gambar 7. Home Warga}

Berikut Gambar 8 yang menjelaskan tentang Halaman Keseluruhan Data Warga.

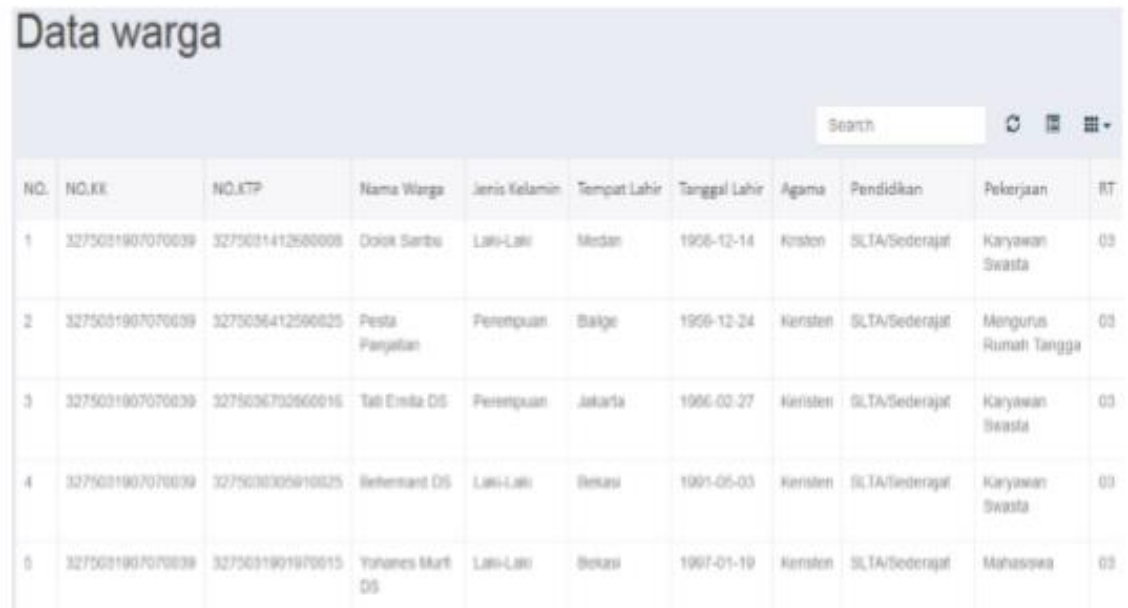

Sumber: Hasil Penelitian (2019)

Gambar 8. Halaman Keseluruhan Data Warga RW.011

Pengujian aplikasi kunjungan berbasis web ini menggunakan pengujian black box testing yaitu pengujian yang dilakukan untuk menguji sistem dan user interface oleh pengguna. Pengujian ini dilakukan untuk memastikan apakah sistem yang dibuat sudah sesuai dengan yang diharapkan atau berhasil menampilkan output sesuai dengan rancangan.

Tabel 2. rancangan pengujian

\begin{tabular}{lll}
\hline \multicolumn{1}{c}{ Deskripsi Pengujian } & \multicolumn{1}{c}{ Detail Pengujian } & Hasil uji \\
\hline Login & $\begin{array}{l}\text { Memasukkan nomer kk/ktp dan password } \\
\text { dengan hal user yang berbeda }\end{array}$ & Blackbox \\
\hline Data warga / tambah warga & $\begin{array}{l}\text { Melihat dan menambah data warga yang sudah } \\
\text { terhubung dengan data base }\end{array}$ & Blackbox \\
& Mensetujui pengajuan permohonan surat & Blackbox \\
\hline Validasi permohonan & Mengisi from permohonan surat & Blackbox \\
\hline Permohonan surat & Melihat surat yang sudah divalidasi oleh admin & Blackbox \\
\hline Download surat & Menampilkan data biodata & Blackbox \\
\hline Biodata & & \\
\hline
\end{tabular}

Sumber: Hasil Pengolahan Data (2019) 
Pada Tabel 3 akan dijelaskan hasil pengujianya yaitu:

Tabel 3. Hasil Pengujian

\begin{tabular}{|c|c|c|c|}
\hline Menu & Skenario & Hasil Yang Diharapkan & Hasil \\
\hline Login & $\begin{array}{l}\text { Memasukkan } \\
\text { kk/ktp dan password } \\
\text { dengan hal user yang } \\
\text { berbeda }\end{array}$ & $\begin{array}{l}\text { User berhasil login dan halaman } \\
\text { yang ditampilkan sesuai dengan jenis } \\
\text { user yang login }\end{array}$ & Berhasil \\
\hline $\begin{array}{l}\text { Data warga / } \\
\text { tambah warga }\end{array}$ & $\begin{array}{l}\text { Melihat dan menambah } \\
\text { data warga yang sudah } \\
\text { terhubung dengan data } \\
\text { base }\end{array}$ & $\begin{array}{l}\text { Data master dapat diubah dan } \\
\text { disimpan kedalam database }\end{array}$ & Berhasil \\
\hline $\begin{array}{l}\text { Validasi } \\
\text { permohonan }\end{array}$ & $\begin{array}{l}\text { Mensetujui pengajuan } \\
\text { permohonan surat }\end{array}$ & $\begin{array}{l}\text { Data telah di ajukan akan masuk ke } \\
\text { dalam data base dan menungu } \\
\text { validasi. }\end{array}$ & Berhasil \\
\hline $\begin{array}{l}\text { Permohonan } \\
\text { surat }\end{array}$ & $\begin{array}{l}\text { Mengisi from permohonan } \\
\text { surat }\end{array}$ & $\begin{array}{l}\text { Data yang harus di isi sebagi } \\
\text { permohonan dan secara otomatis } \\
\text { akan masuk kedalam data base. }\end{array}$ & Berhasil \\
\hline $\begin{array}{l}\text { Download } \\
\text { surat }\end{array}$ & $\begin{array}{l}\text { Melihat surat yang sudah } \\
\text { divalidasi oleh admin }\end{array}$ & $\begin{array}{l}\text { Permohonan yang telah di } \\
\text { validasikan akan di simpan di dalam } \\
\text { data base. }\end{array}$ & Berhasil \\
\hline Biodata & Menampilkan data biodata & $\begin{array}{l}\text { Data yang telah diisi sebagai data } \\
\text { registrasi/login tersimpan secara } \\
\text { otomatis di data base. }\end{array}$ & Berhasil \\
\hline
\end{tabular}

Sumber: Hasil Pengolahan Data (2019)

\section{Kesimpulan}

Berdasarkan hasil dan pembahasan yang dilakukan sebelumnya, dapat disimpulkan sebagai berikut: 1). Sistem Layanan Warga harus terhubung dengan internet agar Sistem informasi ini dapat berjalan sebagaimana mestinya. 2). Pelaksanaan permohonan surat tiap warga berbeda, pada penelitian ini , proses alur permohonan surat melalui website yang sudah di berikan id dan password oleh ketua RT/Admin. 3). Penggunaan Sistem Layanan Warga dianggap mampu memenuhi kebutuhan dalam pelayanan permohonan surat pengantar warga. Beberapa hal yang disarankan yaitu: a). Agar efisien dan menjadikan data update, data basis sebaiknya bisater hubung langsung dengan data basis kelurahan yang terkoneksi langsung dengan kecamatan dan dinas. b). Untuk pengembang selanjutnya diharapkan dapat membuat Sistem Layanan Warga yang lebih baik. c). Pada penelitian mendatang diharapkan dilakukan di Kelurahan yang tergolong mempunyai kualitas jaringan dan sumber daya manusia yang baik dan Diharapkan diadakan pelatihan tentang pengelolaan Sistem Layanan Warga dan penggunaannya.

\section{Daftar Pustaka}

Gustian, H. (2019). Sistem Informasi Forum Diskusi Layanan Mandiri Online Warga Rw09 Kelurahan Karadenan Kecamatan Cibinong Kabupaten Bogor. Jurnal Ikra

Gustian, H.(n.d.). Sistem Informasi Forum Diskusi Layanan Mandiri Online Warga RW09 Kelurahan 
karaden kecamatan cibinong Kabupaten Bogor

Hidayatullah, P., \& Kawistara, J. K. (2015). Pemerograman Web.Bandung: Informatika.

Jepersone. (2014). Konsep Sistem Informasi. Yogyakarta: informatika.

Madium, M. (2016). Pemrograman PHP dan MySQL untuk Pemula. Yogyakarta: ANDI

Pratama, I. (2014). Sistem Informasi dan Implementasinya. Bandung: Informatika.

Rosa, \& Shalahuddin, M. (2014). Rekayasa Perangkat Lunak Terstruktur dan Berorientasi Objek. Bandung: Informatika.

Wahyuningrum, R. (2017). Sistem Forum Diskusi Online Warga RW 02 Kelurahan Jati Kecamatan

Pulogadung Jakarta Timur. Riau Journal Of Comnputer Science, 19. 